\title{
Kangaroo Mother Care and Swaddling Methods In Low Born Weight Babies In Community Settings: A Systematic Review
}

\author{
S. tauriana, Joni Haryanto*, Retnayu Pradanie \\ Faculty Of Nursing, Airlangga University, Indonesia \\ *joni.h.unair@gmail.com
}

\begin{abstract}
Infants born with low birth weight or LBW are very susceptible to hypothermia due to the thin fat reserves under the skin and immature heat regulating centers in the brain. Some alternative treatments to stabilize LBW body temperature, namely the Kangaroo Mother Care and Swaddling Methods. The preparation of this systematic review is to determine the application of Kangaroo mother care and self-help in the community. Methods: in preparing this systematic review using descriptive analysis, JBI protocol guidelines, and analysis of the PICOS framework. The search for articles consisted of five databases, namely Scopus, Science Direct, PubMed, Garuda, and Proquest using the keywords Medical Subject Healing (MeSH) which were then described in a flow diagram. The risk of bias in studies was avoided by using the JBI Critical Appraisal. Analysis of 25 articles on kangaroo mother care and self-care showed that kangaroo mother care can keep the baby's body temperature stable and reduce the risk of hypothermia in newborns with low weight and make it easier for the baby to breastfeed. Unlike the swaddling method, this method does not have a significant impact on the stability of the baby's body temperature or the baby's weight. This systematic review shows that the kangaroo mother care method has a more significant impact on baby weight gain and the stability of the baby's body temperature by maintaining skin to skin contact between mother and baby for later implementation in the community. This method is more effective than the swaddling method.
\end{abstract}

Keywords : Kangaroo Mother Care, Swaddling, Low Birth Weight, Community

Received August 5, 2020; Revised October 3, 2020; Accepted October 26, 2020 


\section{STRADA Jurnal Ilmiah Kesehatan}

DOI: $10.30994 /$ sjik.v9i2.439

ISSN: 2252-3847 (print); 2614-350X (online)

Vol.9 No.2 November 2020 Page.1186-1195

\section{BACKGROUND}

The inability of parents to care for babies, especially babies with low birth weight, and the disconnection of nursing care from the hospital to the home causes the baby's health to be monitored optimally. Education is important as a discharge planning program to help mothers improve their knowledge and skills in caring for their babies (Beheshtipaour Baharlu, Montaseri, \& Ardakanin, 2014). Several alternative treatment methods that are easier, cheaper and more effective in stabilizing LBW body temperature, namely the Kangaroo Mother Care and Swaddling Methods (Bobak, 2012).

In some developed countries, about $2 / 3$ of low birth weight is caused by prematurity, while in developing countries most of the LBW babies are caused by obstructed (Dawar, Nangia, Thukral, Chopra, \& Khanna, 2019) . Nearly 13 million babies are born weighing less than 2500 grams worldwide each year. Of these more than 1 million died within a month after birth. WHO itself defines low birth weight babies as babies born weighing less than 2500 grams (Gardon et al., 2019) .

Upbringing nursing continued in the community is also important to do for the detection of early problems that arise in LBW and facilitate the growth and development of infants. Shaping the behavior of healthy parents in taking care of infants with low birth weight requires efforts continue constantly and implemented in stages, so that mentoring holds the role of an important (Gardon et al., 2019). The communication system between the hospital - health center the family plays an important role in successful care of low birth weight babies after discha rge from the hospital.

\section{METHODS}

The literature search strategy used five electronic databases, namely Scopus, Science Direct, PubMed, ProQuest, Portal Garuda. The search was carried out from April-July 2020 to identify relevant research. Keywords in this Systematic review are adjusted to the Medical Subject Heading (MeSH). The keywords used are Babies care Or Neonatal care and Kangaroo Mother Care and Swaddling and Community Care and Low Birth Weight Babies. The next step is to select articles according to the criteria, namely published in 2015-2020 with full text and in English, in the preparation of this systematic review based on Preferred Reporting Items for Systematic Reviews and Meta-Analyses (PRISMA). The articles that were found were then synthesized and analyzed according to the inclusion and exclusion criteria. The inclusion criteria in this systematic review are (1) Study focuses on mothers with LBW $\leq 2500$ grams (2) Studies that examine Kangaroo Mother Care interventions (3) Standard interventions from health care or self-help (swaddling) (4) Quasi-experimental studies, clinical trial or randomized control led trial, Mix Method and Crosectional. while the exclusion criteria in this systematic review are (1) Studies that discuss the care of normal newborns (2) qualitative research, systematic review or literature reviews. The researcher removes the same articles, examines articles that meet the criteria, and classifies them according to the results of the research to be continued with the discussion.

\section{RESULTS}

Result through five a data base of electronics by using keywords which correspond to the MeSH, researchers get 98 articles that match the keywords are. Researchers perform the selection of the article with the same title, and then the remaining 85 articles. Screening based on the title and then do that adapts to 


\section{STRADA Jurnal Ilmiah Kesehatan}

DOI: $10.30994 /$ sjik.v9i2.439

ISSN: 2252-3847 (print); 2614-350X (online)

Vol.9 No.2 November 2020 Page.1186-1195

the theme of the systematic review, in get as many as 50 articles. Selection is based on an abstract has been in exclusion and get 40 articles. Of the 40 articles later on select appropriate with the criteria of eligibility and get the 25 articles that used in the systematic review. The results of the selection of articles in describing the diagram of flow s sa follows:

Figure 1. Flow diagram and article selection

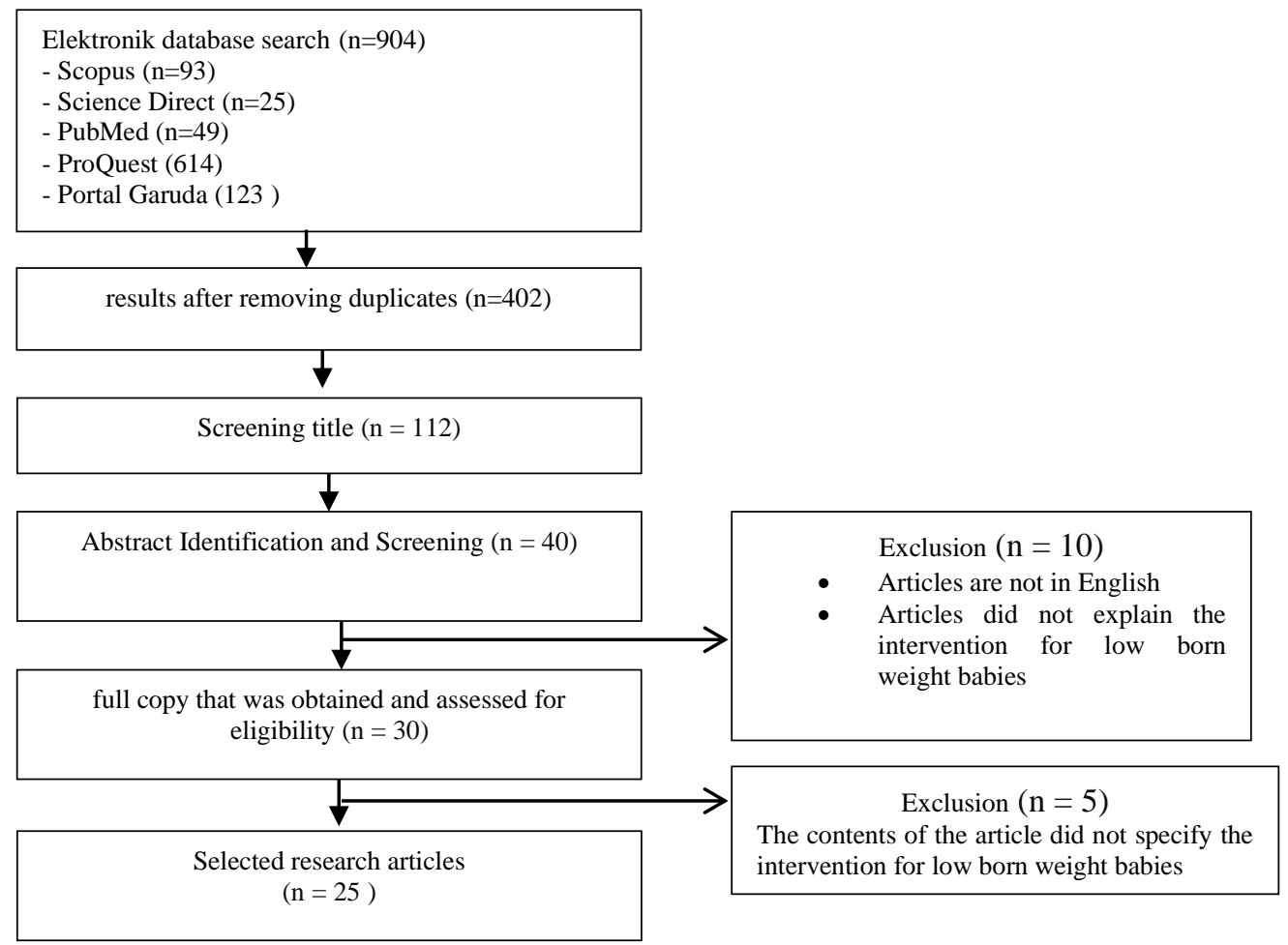

Of the 25 studies that met criteria for Systematic review this in get the results of 25 studies is an Original Research by design Cross Sectional Study of 4 pieces, 3 pieces of the study using a design quasi experimental study, 1 piece studies using 1 piece of studies using mix method and 17 The study used a randomized controlled trial (RCT) design. The studies included in the systematic review articles in this review were carried out in 2015 , namely 2 study articles, 5 study articles conducted in 2016,6 study articles in 201 7, 3 study articles in 2018,3 study articles in 2019 and 6 study articles conducted in 2020. Studies were included in the article systematic review The review is as much as 19 study is a technique of kangaroo mother care and 6 research is the technique of swaddling conducted in communities in the baby just born with low weight with goal warmed up the baby, increasing the baby's weight, increasing contact between mother and children, and maintain the stability of the baby's body temperature. The studies in Systematic review were conducted in Nepal, East Java, Indonesia, Uganda and Malawi. Based on the study results, it was found that the Kangaroo Mother Care and Swaddling methods on low birth weight babies had a positive impact on body te mperature stability and increased baby weight. The results of this study can be seen in Table 1. 
STRADA Jurnal Ilmiah Kesehatan

DOI: $10.30994 /$ sjik.v9i2.439

ISSN: 2252-3847 (print); 2614-350X (online)

Vol.9 No.2 November 2020 Page.1186-1195

Table 1. Characteristics of research articles

\begin{tabular}{|c|c|c|c|c|c|c|}
\hline $\mathrm{NO}$ & TITLE & POPULASI & INTERVENSION & COMPARATION & OUTCOME & STUDY \\
\hline 1. & $\begin{array}{l}\text { Impact of community- } \\
\text { initiated Kangaroo Mother } \\
\text { Care on survival of low birth } \\
\text { weight infants: study protocol } \\
\text { for a randomized controlled } \\
\text { trial (Mazumder et al., 2017) }\end{array}$ & $\begin{array}{l}\text { LBW babies }(1500- \\
2250 \mathrm{~g}) \text { and their } \\
\text { mothers }\end{array}$ & $\begin{array}{l}\text { Kangaroo Mother } \\
\text { Care }\end{array}$ & - & $\begin{array}{l}\text { Kangaroo Mother Care } \\
\text { (KMC) appears to be an } \\
\text { effective way to reduce } \\
\text { mortality and morbidity in } \\
\text { LBW infants. KMC consists } \\
\text { of early and ongoing skin- } \\
\text { to-skin contact between } \\
\text { mother and baby and } \\
\text { exclusive breastfeeding }\end{array}$ & $\begin{array}{l}\text { Randomized } \\
\text { controlled trial }\end{array}$ \\
\hline 2. & $\begin{array}{l}\text { Community initiated } \\
\text { kangaroo mother care and } \\
\text { early child development in } \\
\text { low birth weight infants in } \\
\text { India-a randomized } \\
\text { controlled trial (Taneja et al., } \\
2020 \text { ) }\end{array}$ & $\begin{array}{l}552 \text { stable LBW } \\
\text { infants }\end{array}$ & $\begin{array}{l}\text { Kangaroo Mother } \\
\text { Care }\end{array}$ & - & $\begin{array}{l}\text { There is a significant } \\
\text { increase in the psychomotor } \\
\text { of infants with low body } \\
\text { weight and increase } \\
\text { the percentage of infant surv } \\
\text { ival. }\end{array}$ & $\begin{array}{l}\text { Randomized } \\
\text { controlled trial }\end{array}$ \\
\hline 3 & $\begin{array}{l}\text { A randomized control trial of } \\
\text { hypothermia alert device in } \\
\text { low birth weight newborns } \\
\text { and the effect on kangaroo } \\
\text { mother care and weight gain } \\
\text { (S., Benakappa, Benakappa, } \\
\text { \& Morgan, 2019) }\end{array}$ & 44 neonates & $\begin{array}{l}\text { Kangaroo Mother } \\
\text { Care }\end{array}$ & - & $\begin{array}{l}\text { Kangaroo Mother Care } \\
\text { effective to prevent hypother } \\
\text { mia in infants with low } \\
\text { weight and add weight } \\
\text { babies. }\end{array}$ & $\begin{array}{l}\text { Randomized } \\
\text { controlled trial }\end{array}$ \\
\hline 4 & $\begin{array}{l}\text { Improving Skin-to-Skin } \\
\text { Practice for babies in } \\
\text { Kangaroo Mother Care in } \\
\text { Malawi through the use of a } \\
\text { customized baby wrap: A } \\
\text { randomized control trial } \\
\text { (Chavula et al., 2020) }\end{array}$ & 301 mothers-babies & $\begin{array}{l}\text { Kangaroo Mother } \\
\text { Care }\end{array}$ & - & $\begin{array}{l}\text { Kangaroo mother care is a } \\
\text { skin-to-skin contact method } \\
\text { that is accepted by } \\
\text { mothers as independent care } \\
\text { for babies born with low } \\
\text { body weight. }\end{array}$ & $\begin{array}{l}\text { Randomized } \\
\text { controlled trial }\end{array}$ \\
\hline 5. & $\begin{array}{l}\text { Operationalising kangaroo } \\
\text { Mother care before } \\
\text { stabilisation amongst low } \\
\text { birth Weight Neonates in } \\
\text { Africa (OMWaNA): protocol } \\
\text { for a randomised controlled } \\
\text { trial to examine mortality } \\
\text { impact in Uganda (Medvedev } \\
\text { et al., 2020) }\end{array}$ & 2188 neonates & Kangaroo Mother Care & - & $\begin{array}{l}\text { Kangaroo mother care } \\
\text { can reduce the mortality rate } \\
\text { for low weight babies. }\end{array}$ & $\begin{array}{l}\text { Randomized } \\
\text { controlled trial }\end{array}$ \\
\hline 6 & $\begin{array}{l}\text { Kangaroo Mother Care } \\
\text { (KMC): An Alternative to } \\
\text { Conventional Method of Care } \\
\text { for Low Birth Weight Babies }\end{array}$ & 120 neonates & $\begin{array}{l}\text { Kangaroo Mother } \\
\text { Care }\end{array}$ & $\begin{array}{l}\text { conventional } \\
\text { methods of care }\end{array}$ & $\begin{array}{l}\text { Kangaroo Mother Care } \\
\text { boost growth, } \\
\text { reduce disability, } \\
\text { reduce inpatient hospitalizati } \\
\text { on in LBW infants. }\end{array}$ & $\begin{array}{l}\text { Randomized } \\
\text { controlled trial }\end{array}$ \\
\hline 7. & $\begin{array}{l}\text { Kangaroo Mother Care } 20 \\
\text { Years Later: Connecting } \\
\text { Infants and Families } \\
\text { (Furman, 2017) }\end{array}$ & 3042 infants & $\begin{array}{l}\text { Kangaroo Mother } \\
\text { Care }\end{array}$ & - & $\begin{array}{l}\text { Kangaroo Mother Care } \\
\text { promotes physical contact be } \\
\text { tween mother and baby. }\end{array}$ & $\begin{array}{l}\text { Randomized } \\
\text { controlled trial }\end{array}$ \\
\hline 8. & $\begin{array}{l}\text { Long Term Outcomes of } \\
\text { Kangaroo Mother Care in } \\
\text { Very Low Birth Weight } \\
\text { Infants (Gavhane, Eklare, \& } \\
\text { Mohammad, 2016) }\end{array}$ & 91 infants & Kangaroo Mother Care & - & $\begin{array}{l}\text { Kangaroo Mother Care } \\
\text { effectively increase } \\
\text { the growth } \\
\text { of infants with low birth } \\
\text { weight } 6-12 \text { months. }\end{array}$ & $\begin{array}{l}\text { Randomized } \\
\text { controlled trial }\end{array}$ \\
\hline 9. & $\begin{array}{l}\text { Twenty-year Follow-up of } \\
\text { Kangaroo Mother Care } \\
\text { Versus Traditional Care }\end{array}$ & 716 participants & $\begin{array}{l}\text { Kangaroo Mother } \\
\text { Care }\end{array}$ & Traditional care & $\begin{array}{l}\text { KMC is effective } \\
\text { in shaping children into nor } \\
\text { mal individuals }\end{array}$ & $\begin{array}{l}\text { Randomized } \\
\text { controlled trial }\end{array}$ \\
\hline
\end{tabular}


STRADA Jurnal Ilmiah Kesehatan

DOI: $10.30994 /$ sjik.v9i2.439

ISSN: 2252-3847 (print); 2614-350X (online)

Vol.9 No.2 November 2020 Page.1186-1195

\begin{tabular}{|c|c|c|c|c|c|c|}
\hline & (Charpak et al., 2017) & & & & $\begin{array}{l}\text { without any behavioral devia } \\
\text { tions. }\end{array}$ & \\
\hline 11. & $\begin{array}{l}\text { Impact of continuous } \\
\text { Kangaroo Mother Care } \\
\text { initiated immediately after } \\
\text { birth (KMC) on survival of } \\
\text { newborns with birth weight } \\
\text { between } 1.0 \text { to } \leq 1.8 \mathrm{~kg} \\
\text { (Adejuyigbe et al., 2020) }\end{array}$ & 4200 neonates & $\begin{array}{l}\text { Kangaroo Mother } \\
\text { Care }\end{array}$ & - & $\begin{array}{l}\text { KMC method } \\
\text { mampum Enhancing the } \\
\text { numbers continuity of } \\
\text { life infants with severe bada } \\
\text { n low.. }\end{array}$ & $\begin{array}{l}\text { Randomized } \\
\text { controlled trial }\end{array}$ \\
\hline 12. & $\begin{array}{l}\text { The effects of kangaroo } \\
\text { mother care on the time to } \\
\text { breastfeeding initiation } \\
\text { among preterm and LBW } \\
\text { infants (Mekonnen, } \\
\text { Yehualashet, \& Bayleyegn, } \\
\text { 2019) }\end{array}$ & 467 infants & $\begin{array}{l}\text { Kangaroo Mother } \\
\text { Care }\end{array}$ & - & $\begin{array}{l}\text { The KMC method is } \\
\text { effective } \\
\text { in increasing breastfeeding } \\
\text { in infants with low body } \\
\text { weight. }\end{array}$ & $\begin{array}{l}\text { Randomized } \\
\text { controlled trial }\end{array}$ \\
\hline 13 & $\begin{array}{l}\text { Thermoregulatory effects of } \\
\text { swaddling in Mongolia: a } \\
\text { randomised controlled study } \\
\text { (Tsogt, Manaseki-Holland, } \\
\text { Pollock, Blair, \& Fleming, } \\
\text { 2016) }\end{array}$ & 40 Bayi & Swaddling & - & $\begin{array}{l}\text { Swaddling has no thermal ad } \\
\text { vantage }\end{array}$ & $\begin{array}{l}\text { Randomized } \\
\text { controlled trial }\end{array}$ \\
\hline 14 & $\begin{array}{l}\text { The Effects of Kangaroo } \\
\text { Mother Care and Swaddling } \\
\text { on VenipuncturePain in } \\
\text { Premature Neonates: A } \\
\text { Randomized Clinical Trial } \\
\text { (Dezhdar, Jahanpour, Bakht, } \\
\text { \& Ostovar, 2016) }\end{array}$ & 90 Bayi & Swaddling and KMC & - & $\begin{array}{l}\text { Research } \\
\text { results have showed that is } \\
\text { not no difference significantl } \\
\text { y between swaddling and } \\
\text { KMC } \\
\text { are physiological indices }\end{array}$ & $\begin{array}{l}\text { Randomized } \\
\text { controlled trial }\end{array}$ \\
\hline 15 & $\begin{array}{l}\text { Changes in autonomic } \\
\text { regulation due to Kangaroo } \\
\text { care remain unaffected by } \\
\text { using a swaddling device } \\
\text { (Kommers et al., 2019) }\end{array}$ & 20 Bayi & Swaddling and KMC & - & $\begin{array}{l}\text { The } \\
\text { use of alternative swaddlers } \\
\text { aimed at facilitating kangaro } \\
\text { o care does } \\
\text { not increase autonomic regul } \\
\text { ation, as measured by vital } \\
\text { signs } \\
\text { and heart rate variability. }\end{array}$ & Observasi \\
\hline 16 & $\begin{array}{l}\text { Operationalising kangaroo } \\
\text { Mother care before } \\
\text { stabilisation amongst low } \\
\text { birth Weight Neonates in } \\
\text { Africa (OMWaNA): protocol } \\
\text { for a randomised controlled } \\
\text { trial to examine mortality } \\
\text { impact in Uganda (Medvedev } \\
\text { et al., 2020) }\end{array}$ & 2188 neonates & $\begin{array}{l}\text { Kangaroo Mother } \\
\text { Care }\end{array}$ & - & $\begin{array}{l}\text { Kangaroo mother care } \\
\text { can reduce the mortality rate } \\
\text { for low weight babies. }\end{array}$ & $\begin{array}{l}\text { randomized } \\
\text { controlled trial }\end{array}$ \\
\hline 17 & $\begin{array}{l}\text { Effect of community-initiated } \\
\text { kangaroo mother care on } \\
\text { survival of infants with low } \\
\text { birthweight: a randomised } \\
\text { controlled trial (Mazumder et } \\
\text { al., 2019) }\end{array}$ & $\begin{array}{l}8402 \text { babies weighing } \\
1500-2250 \mathrm{~g}\end{array}$ & $\begin{array}{l}\text { Kangaroo Mother } \\
\text { Care }\end{array}$ & - & $\begin{array}{l}\text { Kangaroo Mother Care is } \\
\text { effective in reducing infant } \\
\text { mortality. }\end{array}$ & $\begin{array}{l}\text { Randomized } \\
\text { controlled trial }\end{array}$ \\
\hline 18 & $\begin{array}{l}\text { The Effect of Kangaroo } \\
\text { Mother Care with Weight } \\
\text { Gain in Low Birth Weight } \\
\text { Infant in Kediri, East Java, } \\
\text { Indonesia (Florentis, Nur, \& } \\
\text { Sari, 2016) }\end{array}$ & 62 infants & Kangaroo Mother Care & - & $\begin{array}{l}\text { KMC can increase the } \\
\text { baby's } \\
\text { weight more quickly than th } \\
\text { ose not using the methods of } \\
\text { KMC.. }\end{array}$ & Quasyexperimental \\
\hline 19 & $\begin{array}{l}\text { Effects of nesting and } \\
\text { swaddling on the sleep } \\
\text { duration of premature infants }\end{array}$ & 42 preterm infants & Swaddling & Nesting & $\begin{array}{l}\text { Both methods are equally ha } \\
\text { ve pengaru h significantly to } \\
\text { the duration of sleep a } \\
\text { baby just born with low }\end{array}$ & $\begin{array}{l}\text { crossover clinical } \\
\text { trial }\end{array}$ \\
\hline
\end{tabular}




\section{STRADA Jurnal Ilmiah Kesehatan}

DOI: $10.30994 /$ sjik.v9i2.439

ISSN: 2252-3847 (print); 2614-350X (online)

Vol.9 No.2 November 2020 Page.1186-1195

\begin{tabular}{|c|c|c|c|c|c|c|}
\hline & $\begin{array}{l}\text { hospitalized in neonatal } \\
\text { intensive care units (Zahra } \\
\text { Abdeyazdan, Mohammadian- } \\
\text { Ghahfarokhi, Ghazavi, \& } \\
\text { Mohammadizadeh, 2016) }\end{array}$ & & & & weight. & \\
\hline 20 & $\begin{array}{l}\text { The Effect Of Early } \\
\text { Intermittent Kangaroo } \\
\text { Mother Care On Neonatal } \\
\text { Mortality, Morbidity And } \\
\text { Weight Gain In Stable Low } \\
\text { Birth Weight Infants }\end{array}$ & 343 LBW infants & Kangaroo Mother Care & - & $\begin{array}{l}\text { KMC method is effective } \\
\text { in increasing the baby's } \\
\text { weight, } \\
\text { reducing the mortality rate f } \\
\text { or infants with low body } \\
\text { weight. }\end{array}$ & $\begin{array}{l}\text { Quasi-experimental } \\
\text { study }\end{array}$ \\
\hline 21 & $\begin{array}{l}\text { Effects of traditional } \\
\text { swaddling on development } \\
\text { (Manaseki-Holland et al., } \\
\text { 2010) }\end{array}$ & 1279 Bayi & Swaddling & - & $\begin{array}{l}\text { Swaddling or swaddling in } \\
\text { a long time in } \\
\text { the first life did not have a } \\
\text { significant impact on mental } \\
\text { development } \\
\text { or psychomotor baby. }\end{array}$ & $\begin{array}{l}\text { Randomized } \\
\text { controlled trial }\end{array}$ \\
\hline 22 & $\begin{array}{l}\text { Risks and Benefits of } \\
\text { Swaddling Healthy Infants: } \\
\text { An Integrative Review } \\
\text { (Nelson, 2017) }\end{array}$ & - & Swaddling & - & $\begin{array}{l}\text { Swaddling soothe the baby } \\
\text { and encourage sleep, } \\
\text { but equally or less effective t } \\
\text { han the methods of non- } \\
\text { pharmacological more }\end{array}$ & $\begin{array}{l}\text { A table summarizes } \\
\text { study details }\end{array}$ \\
\hline 23 & $\begin{array}{l}\text { Reinforcing kangaroo mother } \\
\text { care uptake in resource } \\
\text { limited settings (Daga, 2018) }\end{array}$ & 6 infants & Kangaroo Mother Care & - & $\begin{array}{l}\text { The KMC method can } \\
\text { reduce the risk of } \\
\text { hypothermia in LBW }\end{array}$ & $\begin{array}{l}\text { retrospective } \\
\text { observational study }\end{array}$ \\
\hline 24 & $\begin{array}{l}\text { The Effect of Kangaroo } \\
\text { Mother Care Method toward } \\
\text { Weight Gain and Length of } \\
\text { Stay among Low Birth } \\
\text { Weight Baby (Muliani \& } \\
\text { Lisnawati, 2018) }\end{array}$ & 36 babies & Kangaroo Mother Care & - & $\begin{array}{l}\text { The KMC method is } \\
\text { effective in increasing the } \\
\text { baby's weight. }\end{array}$ & $\begin{array}{l}\text { Quasi-experimental } \\
\text { study }\end{array}$ \\
\hline 25 & $\begin{array}{l}\text { Feasibility assessment of an } \\
\text { ergonomic baby wrap for } \\
\text { kangaroo mother care: A } \\
\text { mixed methods study from } \\
\text { Nepal (Thapa et al., 2018) }\end{array}$ & 96 families & Kangaroo Mother Care & - & $\begin{array}{l}\text { The KMC method is } \\
\text { effective for keeping } \\
\text { the baby warm at home. }\end{array}$ & Mix method \\
\hline
\end{tabular}

\section{DISCUSSION}

Birth weight is low (LBW) is a matter of health major public, especially in developing countries, and is often associated with morbidity and mortality in infants (Mahumud, Sultana, \& Sarker, 2017). Low birth weight causes many problems in babies (Wandschneider, Sauzet, Breckenkamp, Spallek, \& Razum, 2020). Conditions are often times associated with the method of kangaroo mother care . Kangaroo Mother Care is a method conventionally often used as an intervention in the baby just born with low weight with the purpose of helping improve the weight and keep the baby stays warm. Kangaroo Mother Care is a method that uses the skin to skin contact between mother and baby that can facilitate mothers to breastfeed babies are exclusively (Conde-Agudelo \& DíazRossello, 2017). Methods that can lower the risk of the occurrence of hypothermia in infants newly born with low birth weight (Mellis, 2016) as well as lowering the risk of defects in babies just born with low birth weight (Esewe \& Phetlhu, 2020). Kangaroo Mother Care can improve the quality of life the baby new born during the period of life of vulnerable babies are a thousand days first life (Charpak \& Prevost, 2018). Methods that can be done by an independent mother or father (Lopes et al., 2019), 


\section{STRADA Jurnal Ilmiah Kesehatan}

DOI: $10.30994 /$ sjik.v9i2.439

ISSN: 2252-3847 (print); 2614-350X (online)

Vol.9 No.2 November 2020 Page.1186-1195

as well as members of other families who become caregivers baby just born with low weight. The application of the kangaroo mother care method at home is carried out to maintain the stability of the body temperature of infants who are prone to hypothermia (Thapa et al., 2018). Baby just born with low birth weight are treated in the community have a risk of more high against the incidence of hypothermia (Daga, 2018).

Hypothermia susceptible occur in babies just born with low birth weight (Johnson, Thompson, \& Valle, 2019), that are affected by the instability of the temperature of the body of the baby. To maintain the stability of the temperature of the body of a new baby is born with low weight, skin to skin contact becomes easy method implemented with significant results as well as to support and facilitate the implementation of exclusive breastfeeding in infants newly born with low weight so as to encourage an increase in weight (Chowdhury et al., 2019).

Methods swaddling or better known as widely as a method of "swaddling" a method of wrapping a baby with a cloth to help baby sleep more soundly and restrict the movement of the baby (Pease et al., 2016). Methods are applied by wrapping the baby up to the limit of the neck to a comfortable position for a baby just born (Jose, 2017). Wrapping the baby just born with low weight to use cloth thick smooth to prevent skin irritation baby (Dinh, 2019). The fabric used has the characteristics of thick -shaped square- length to facilitate use in infants newly born (Zeidman, 2017).

The kangaroo mother care method is said to be more effective at increasing the baby's body temperature (Hakimi et al., 2017)compared to the swaddling method which does not have a thermal advantage (Tsogt et al., 2016). The swaddling method can be a follow-up care after the kangaroo mother care method to maintain warmth for low-weight newborns in the community (Kommers et al., 2019) but it cannot increase the baby's body temperature. The two methods have different functions as a treatment for low birth weight newborns as well as the positive effects that are related to increasing and maintaining a stable body temperature of newborns with low weight in the community.

After a descriptive analysis, these two methods are often used as a treatment method for low birth weight newborns by families. Every newborn with low weight needs Kangaroo mother care measures to increase the baby's body temperature as well as a swaddling method to maintain the baby's body temperature. The two methods are mutually sustainable in the care of newborns with low weight independently by families in the community.

\section{CONCLUSION}

Methods kangaroo mother care is effectively maintain the stability of the temperature of the body of a baby with lowering the risk of occurrence of hypothermia. Methods that can be applied as independent by the mother, father or any other family who became caregiver baby just born with a low birth weight in the community. Kangaroo mother care is significantly demonstrated impact positively to the baby just born with low birth weight in the community compared with the method of swaddling.

\section{REFERENCES}

Adejuyigbe, E. A., Anand, P., Ansong, D., Anyabolu, C. H., Arya, S., Assenga, E., ... Yoshida, S. (2020). Impact of continuous Kangaroo Mother Care initiated immediately after birth (iKMC) on survival of newborns with birth weight between 1.0 to $<1.8 \mathrm{~kg}$ : Study protocol for a randomized controlled trial. Trials, 21(1), 1-27. 


\section{STRADA Jurnal Ilmiah Kesehatan}

DOI: $10.30994 /$ sjik.v9i2.439

ISSN: 2252-3847 (print); 2614-350X (online)

Vol.9 No.2 November 2020 Page.1186-1195

https://doi.org/10.1186/s13063-020-4101-1

Charpak, N., \& Prevost, V. (2018). The Kangaroo Mother Care method: An old innovation still on agenda to save lives. Medecine Therapeutique Pediatrie, 21(3), 178-192. https://doi.org/10.1684/mtp.2018.0693

Charpak, N., Tessier, R., Ruiz, J. G., Hernandez, J. T., Uriza, F., Villegas, J., ... Maldonado, D. (2017). Twenty-year follow-up of kangaroo mother care versus traditional care. Pediatrics, 139(1), 1-10. https://doi.org/10.1542/peds.2016-2063

Chavula, K., Guenther, T., Valsangkar, B., Lwesha, V., Banda, G., Wensaas, M. B., ... Dube, Q. (2020). Improving skin-to-skin practice for babies in kangaroo mother care in Malawi through the use of a customized baby wrap: A randomized control trial. PLoS ONE, 15(3), 1-16. https://doi.org/10.1371/journal.pone.0229720

Chowdhury, R. M., Sahidullah, M., Mannan, M. A., Chowdhury, M. A., Biswas, B. C., \& Das, K. P. (2019). Comparison between Kangaroo Mother Care with Standard Care in Preterm Neonate Management. Bangladesh Medical Journal, 47(3), 1-8. https://doi.org/10.3329/bmj.v47i3.43491

Conde-Agudelo, A., \& Díaz-Rossello, J. L. (2017). Kangaroo mother care to reduce morbidity and mortality in low birthweight infants ( Review ) SUMMARY OF FINDINGS FOR THE MAIN COMPARISON. Cochrane Library, (8), 153. https://doi.org/10.1002/14651858.CD002771.pub4.www.cochranelibrary.com

Daga, S. (2018). Reinforcing kangaroo mother care uptake in resource limited settings. Maternal Health, Neonatology and Perinatology, 4(1), 1-5. https://doi.org/10.1186/s40748-018-0091-3

Dawar, R., Nangia, S., Thukral, A., Chopra, S., \& Khanna, R. (2019). Factors Impacting Practice of Home Kangaroo Mother Care with Low Birth Weight Infants Following Hospital Discharge. 1-8. https://doi.org/10.1093/tropej/fmz007

Dezhdar, S., Jahanpour, F., Bakht, S. F., \& Ostovar, A. (2016). The effects of kangaroo mother care and swaddling on venipuncture pain in premature neonates: A randomized clinical trial. Iranian Red Crescent Medical Journal, 18(4). https://doi.org/10.5812/ircmj.29649

Dinh, T. (2019). SLEEVED BLANKET FOR SWADDLING AND BEDDING INFANTS. 2(12).

Esewe, R. E., \& Phetlhu, R. D. (2020). Strategies to Enhance Early Implementation of Kangaroo Mother Care Guidelines in Health Facilities in Edo State , Nigeria. 7(1), 46-55.

Florentis, B., Nur, E., \& Sari, E. (2016). View of The Effect of Kangaroo Mother Care with Weight Gain in Low Birth Weight Infant in Kediri, East Java, Indonesia. 788-792.

Furman, L. (2017). Kangaroo mother care 20 years later: Connecting infants and families. Pediatrics, 139(1), 10-13. https://doi.org/10.1542/peds.2016-3332

Gardon, L., Picciolini, O., Squarza, C., Frigerio, A., Lorella, M., Gangi, S., ... Mosca, F. (2019). Early Human Development Neurodevelopmental outcome and adaptive behaviour in extremely low birth weight infants at 2 years of corrected age. Early Human Development, 128(October 2018), 81-85. https://doi.org/10.1016/j.earlhumdev.2018.12.013

Gavhane, S., Eklare, D., \& Mohammad, H. (2016). Long term outcomes of kangaroo mother care in very low birth weight infants. Journal of Clinical and Diagnostic Research, 10(12), SC13-SC15. https://doi.org/10.7860/JCDR/2016/23855.9006

Hakimi, S., Mohammadi, M., Akrami, F., Habibelahi, A., Ranjbar, M., Mirnia, K., \& Heidarzadeh, M. (2017). Pharmacophore ADAPTATION AND BARRIERS OF 


\section{STRADA Jurnal Ilmiah Kesehatan}

DOI: $10.30994 /$ sjik.v9i2.439

ISSN: 2252-3847 (print); 2614-350X (online)

Vol.9 No.2 November 2020 Page.1186-1195

HOME BASED KANGAROO MOTHER CARE IN LOW BIRTH WEIGHT INFANTS. 8 (March).

Johnson, H., Thompson, T., \& Valle, D. (2019). Baby It â $€^{T M} s$ Cold Outside: Effectiveness of Skin to Skin in Preventing Hypothermia in Low Birth Weight Infants. 20037611.

Jose, S. (2017). The Simple Swaddler. 1.

Kommers, D. R., Joshi, R., van Pul, C., Feijs, L., Bambang Oetomo, S., \& Andriessen, P. (2019). Changes in autonomic regulation due to Kangaroo care remain unaffected by using a swaddling device. Acta Paediatrica, International Journal of Paediatrics, 108(2), 258-265. https://doi.org/10.1111/apa.14484

Lopes, T. R. G., Carvalho, J. B. L. de, Alves, T. R. M., Medeiros, A. B. de, Oliveira, S. S. de, \& Miranda, F. A. N. de. (2019). Vivência de pais com o Método Canguru: revisão integrativa. Rev Rene, 20, e41687. https://doi.org/10.15253/2175-6783.20192041687

Mahumud, R. A., Sultana, M., \& Sarker, A. R. (2017). Distribution and determinants of low birth weight in developing countries. Journal of Preventive Medicine and Public Health, 50(1), 18-28. https://doi.org/10.3961/jpmph.16.087

Manaseki-Holland, S., Spier, E., Bavuusuren, B., Bayandorj, T., Sprachman, S., \& Marshall, T. (2010). Effects of traditional swaddling on development: A randomized controlled trial. Pediatrics, 126(6). https://doi.org/10.1542/peds.2009-1531

Mazumder, S., Taneja, S., Dalpath, S. K., Gupta, R., Dube, B., Sinha, B., ... Martines, J. (2017). Impact of community-initiated Kangaroo Mother Care on survival of low birth weight infants: Study protocol for a randomized controlled trial. Trials, 18(1), 1-10. https://doi.org/10.1186/s13063-017-1991-7

Mazumder, S., Taneja, S., Dube, B., Bhatia, K., Ghosh, R., Shekhar, M., ... Bhandari, N. (2019). Effect of community-initiated kangaroo mother care on survival of infants with low birthweight: a randomised controlled trial. The Lancet, 394(10210), 17241736. https://doi.org/10.1016/S0140-6736(19)32223-8

Medvedev, M. M., Tumukunde, V., Mambule, I., Tann, C. J., Waiswa, P., Canter, R. R., ... Lawn, J. E. (2020). Operationalising kangaroo Mother care before stabilisation amongst low birth Weight Neonates in Africa (OMWaNA): Protocol for a randomised controlled trial to examine mortality impact in Uganda. Trials, 21(1), 119. https://doi.org/10.1186/s13063-019-4044-6

Mekonnen, A. G., Yehualashet, S. S., \& Bayleyegn, A. D. (2019). The effects of kangaroo mother care on the time to breastfeeding initiation among preterm and LBW infants: A meta-analysis of published studies. International Breastfeeding Journal, 14(1), 1217. https://doi.org/10.1186/s13006-019-0206-0

Mellis, C. (2016). Kangaroo Mother Care and neonatal outcomes: A meta-analysis. Journal of Paediatrics and Child Health, 52(5), 579. https://doi.org/10.1111/jpc.13218

Muliani, M., \& Lisnawati, L. (2018). The Effect of Kangaroo Mother Care Method toward Weight Gain and Length of Stay among Low Birth Weight Baby. International Journal of Public Health Science (IJPHS), 7(2), 91. https://doi.org/10.11591/ijphs.v7i2.12632

Nelson, A. M. (2017). Risks and Benefits of Swaddling Healthy Infants: An Integrative Review. MNC Journal. https://doi.org/2017 doi: 10.1097/NMC.0000000000000344

Pease, A. S., Fleming, P. J., Hauck, F. R., Moon, R. Y., Horne, R. S. C., L'hoir, M. P., ... Blair, P. S. (2016). Swaddling and the risk of sudden infant death syndrome: A Metaanalysis. Pediatrics, 137(6). https://doi.org/10.1542/peds.2015-3275 


\section{STRADA Jurnal Ilmiah Kesehatan}

DOI: $10.30994 /$ sjik.v9i2.439

ISSN: 2252-3847 (print); 2614-350X (online)

Vol.9 No.2 November 2020 Page.1186-1195

S., J. A., Benakappa, A., Benakappa, N., \& Morgan, G. (2019). A randomized control trial of hypothermia alert device in low birth weight newborns and the effect on kangaroo mother care and weight gain. International Journal of Contemporary Pediatrics, 7(1), 52. https://doi.org/10.18203/2349-3291.ijcp20195725

Taneja, S., Sinha, B., Upadhyay, R. P., Mazumder, S., Sommerfelt, H., Martines, J., ... Dube, B. (2020). Community initiated kangaroo mother care and early child development in low birth weight infants in India-a randomized controlled trial. BMC Pediatrics, 20(1), 1-12. https://doi.org/10.1186/s12887-020-02046-4

Thapa, K., Mohan, D., Williams, E., Rai, C., Bista, S., Mishra, S., \& Hamal, P. K. (2018). Feasibility assessment of an ergonomic baby wrap for kangaroo mother care: A mixed methods study from Nepal. PLoS ONE, 13(11), 1-16. https://doi.org/10.1371/journal.pone.0207206

Tsogt, B., Manaseki-Holland, S., Pollock, J., Blair, P. S., \& Fleming, P. (2016). Thermoregulatory effects of swaddling in Mongolia: A randomised controlled study. Archives of Disease in Childhood, 101(2), 152-160. https://doi.org/10.1136/archdischild-2014-307908

Wandschneider, L., Sauzet, O., Breckenkamp, J., Spallek, J., \& Razum, O. (2020). SmallArea Factors and Their Impact on Low Birth Weight-Results of a Birth Cohort Study in Bielefeld, Germany. Frontiers in Public Health, 8(April), 1-10. https://doi.org/10.3389/fpubh.2020.00136

Zahra Abdeyazdan, Mohammadian-Ghahfarokhi, M., Ghazavi, Z., \& Mohammadizadeh, M. (2016). Effects of nesting and swaddling on the sleep duration of premature infants hospitalized in neonatal intensive care units. PubMed, 21, 552-556. https://doi.org/doi: 10.4103/1735-9066.193422

Zeidman, H. R. . (2017). SWADDLING BLANKET AND POUCH COMBINATION. 